\title{
Influence of humic acid and poultry manure on nutrient content and their uptake by $T$. aman rice
}

\author{
R. Saha ${ }^{1}$, M. A. U. Saieed ${ }^{2^{*}}$, M. A. K. Chowdhury ${ }^{1}$ and M. A. H. Chowdhury ${ }^{1}$ \\ ${ }^{1}$ Department of Agricultural Chemistry and ${ }^{2}$ Department of Seed Science and Technology, Bangladesh Agricultural \\ University, Mymensingh-2202, Bangladesh, *E-mail: atiksst@gmail.com
}

\begin{abstract}
A study was conducted to examine the nutrient content and their uptake of rice as influenced by the application of humic acid (HA) and poultry manure (PM). This experiment was laid out in a Randomized Complete Block Design (RCBD) with three replications. Three levels each of humic acid $\left(0,3\right.$ and $\left.6 \mathrm{~L} \mathrm{ha}^{-1}\right)$ and poultry manure $(0,3$ and $6 \mathrm{t}$ $\mathrm{ha}^{-1}$ ) were applied. BRRI dhan39 was used as test crop. Basal doses of $\mathrm{N}, \mathrm{P}, \mathrm{K}$ and $\mathrm{S}$ fertilizers were applied. Both humic acid and poultry manure either singly or in combination significantly affected the contents and uptake of N, P, $\mathrm{K}, \mathrm{S}, \mathrm{Ca}$ and $\mathrm{Mg}$ of BRRI dhan39. The maximum content of $\mathrm{N}, \mathrm{P}, \mathrm{K}, \mathrm{S}$ and $\mathrm{Ca}$ except $\mathrm{Mg}$ and their uptake were recorded from the treatment combination of $6 \mathrm{~L} \mathrm{ha}^{-1}$ humic acid along with $3 \mathrm{tha}^{-1}$ poultry manure.
\end{abstract}

Keywords: Humic acid, Poultry manure, Nutrient content and uptake, BRRI dhan39

\section{Introduction}

Rice is the main staple food of Bangladesh. The annual rice production in Bangladesh is about $4,37,29,000$ metric tons (IRRI, 2006). The average yield of rice is $3.90 \mathrm{t} \mathrm{ha}^{-1}$ (BRRI, 2007). In Bangladesh, most of the cultivated soils have less than $1.5 \%$ organic matter. Continuous use of chemical fertilizers accelerated the depletion of soil organic matter and impairs physical and chemical properties of soil in addition to causing micronutrient deficiencies. This important component of soil is declining with time. Humic acid is one of the major components of humic substances. Humic matter is formed through the chemical and biological humification of plant and animal matter and through the biological activities of microorganisms (Anonymous, 2010). Humic acid improves the physical, chemical and biological properties of the soil and influences plant growth. Humic substances are recognised as a key component of soil fertility properties, since they control chemical and biological properties of the rhizosphere (Rengrudkij and Partida, 2003, Nardi et al., 2005, Trevisan et al., 2009). The effects of humic substances have been directly correlated with enhanced uptake of macronutrients, such as N, P and S, and micronutrients like Fe, Zn, Cu and Mn (Pettit, 2004, Chen et al., 2001). The mechanism of humic acid activity in promoting plant growth is not completely known, but several explanations have been proposed by some researchers such as increasing cell membrane permeability, oxygen uptake, respiration and photosynthesis, phosphate uptake, and root cell elongation (Cacco and Dell'Agnolla, 1984; Türkmen et al., 2004; Petronio et al., 1982). Poultry manure is an excellent source of nutrients and can be incorporated into most of the fertilizer programs. Those using manures must practice sound soil fertility management to prevent nutrient imbalances and associated animal health risks as well as surface-water and groundwater contamination. Global environment pollution can also be reduced considerably by reducing the use of chemical fertilizers and increasing the use of cowdung, poultry manure, rice straw and others. Hence a study aiming at the effect of humic acid and poultry manure on nutrient content and their uptake by rice was undertaken.

\section{Materials and Methods}

The experiment was conducted at central farm of Bangladesh Agricultural University, Mymensingh from August to November, 2010. Rice cultivar BRRI dhan39 was used as test crop. There were 9 treatments consisting of three rates of humic acid $\left(0,3\right.$ and $\left.6 \mathrm{~L} \mathrm{ha}^{-1}\right)$ and three rates of poultry manure $(0,3$ and $6 \mathrm{t}$ $\left.\mathrm{ha}^{-1}\right)$. Humic acid was collected from Global Agrovat Company Limited and poultry manure was collected from the Poultry Farm of Bangladesh Agricultural University, Mymensingh. Humic acid was used in liquid form. The experimental treatments were $T_{0}=H A_{0}+P M_{0}$ (control), $T_{1}=H A_{0}+P_{3}, T_{2}=H A_{0}+P M_{6}, T_{3}=$ $\mathrm{HA}_{3}+\mathrm{PM}_{0}, \mathrm{~T}_{4}=\mathrm{HA}_{3}+\mathrm{PM}_{3}, \mathrm{~T}_{5}=\mathrm{HA}_{3}+\mathrm{PM}_{6}, \mathrm{~T}_{6}=\mathrm{HA}_{6}+\mathrm{PM}_{0}, \mathrm{~T}_{7}=\mathrm{HA}_{6}+\mathrm{PM}_{3}$ and $\mathrm{T}_{8}=\mathrm{HA}_{6}+\mathrm{PM}_{6}$. The doses of $\mathrm{N}, \mathrm{P}, \mathrm{K}$ and $\mathrm{S}$ fertilizers were as per the recommendations made by Bangladesh Rice Research Institute (BRRI) and that was $150 \mathrm{~kg} \mathrm{ha}^{-1}$ urea $\left(69 \mathrm{~kg} \mathrm{~N} \mathrm{ha}^{-1}\right), 100 \mathrm{~kg} \mathrm{ha}^{-1}$ TSP, $70 \mathrm{~kg} \mathrm{ha}^{-1}$ MOP and $10 \mathrm{~kg} \mathrm{ha}^{-1}$ gypsum. Land was prepared by ploughing and cross-ploughing with the help of power tiller and leveled 
with ladder. The experiment was laid out in a randomized complete block design with three replications. The unit plot size was $10 \mathrm{~m}^{2}(4.0 \mathrm{~m} \times 2.5 \mathrm{~m}) .25$ day old seedlings were transplanted with the spacing of $15 \mathrm{~cm} \times 20 \mathrm{~cm}$. Intercultural operations were practiced as and when necessary. The crop was harvested on 17th November, 2010. The plant was threshed and grain and straw was collected plot-wise. The soil sample was analyzed for particle size, $\mathrm{pH}$ and determination of organic matter, total $\mathrm{N}$, available $\mathrm{P}$, exchangeable $\mathrm{K}$, cation exchange capacity and plant sample was analyzed for determination of $\mathrm{N}, \mathrm{P}, \mathrm{K}$, $\mathrm{S}, \mathrm{Ca}$ and $\mathrm{Mg}$ dontents. Grain and straw samples were dried in an oven at $65^{\circ} \mathrm{C}$ for 48 hours and then ground after cooling. Grain and straw samples were digested by wet oxidation method using diacid mixture $\left(\mathrm{HNO}_{3}: \mathrm{HClO}_{4}=2: 1\right)$ for the analysis of nutrients under consideration as described by Jackson (1962). The content of $\mathrm{N}$ was determined by semi-micro kjeldahl method followed by Jackson (1962). The concentrations of $P$ and $S$ were analysed with the help of a spectrophotometer at 660 and $420 \mathrm{~nm}$ wavelength, respectively (Jackson, 1962; Tandon, 1995). Potassium concentration was determined directly with the help of a flame photometer (Jackson, 1962). The contents of $\mathrm{Ca}$ and $\mathrm{Mg}$ were determined by EDTA titrimetric method (Page et al., 1982). Nutrient uptake was calculated by the following formula:

Nutrient uptake $\left(\mathrm{kg} \mathrm{ha}^{-1}\right)=\frac{\text { Minerals constituent }(\%) \times \text { Dry matter weight }\left(\mathrm{kg} \mathrm{ha}^{-1}\right)}{100}$

Data were statistically analyzed using the MSTAT statistical Computer Package Programme (Gomez \& Gomez, 1984).

\section{Results and Discussion}

\section{Nutrient contents of rice grain and straw}

Nitrogen: Nitrogen content was significantly influenced by the application of humic acid and poultry manure in grain and straw. The highest $\mathrm{N}$ content was obtained in both grain $(1.38 \%)$ and straw $(0.89 \%)$ by the application of $6 \mathrm{~L} \mathrm{ha}^{-1}$ humic acid and the lowest $(1.29 \%$ and $0.44 \%$, respectively) was recorded in control (Table 1). These findings were partially supported by Govindasamy and Chandrasekaran (2002) who stated that the addition of humic acid was found to increase the content and enhance the uptake of $\mathrm{N}, \mathrm{P}, \mathrm{K}, \mathrm{Ca}, \mathrm{Mg}, \mathrm{Fe}, \mathrm{Mn}$ and $\mathrm{Zn}$ by rice. The highest $\mathrm{N}$ content $(1.37 \%)$ in grain was obtained by the application of $6 \mathrm{t} \mathrm{ha}^{-1}$ poultry manure which was similar to $3 \mathrm{t} \mathrm{ha}^{-1}$ and the lowest $\mathrm{N}$ content $(1.28 \%)$ was recorded at control (Table 2). The highest $\mathrm{N}$ content $(0.74 \%)$ in straw was recorded by the application of $6 \mathrm{t} \mathrm{ha}^{-1}$ poultry manure and the lowest $(0.59 \%)$ was at $\mathrm{PM}_{0}$. The interaction effect of humic acid and poultry manure was statistically significant in grain (Table 3 ). The highest $\mathrm{N}$ content $(1.43 \%)$ was obtained in grain by the combined application of $6 \mathrm{~L} \mathrm{ha}^{-1}$ humic acid and $3 \mathrm{tha}^{-1}$ poultry manure while the lowest $\mathrm{N}$ content $(1.21 \%)$ was found in $\mathrm{T}_{0}$ (control) treatment. Interaction effect of humic acid and poultry manure was insignificant in straw for $\mathrm{N}$ content.

Phosphorus: Phosphorus content in grain and straw was significantly influenced by the application of humic acid and poultry manure. The highest phosphorus content in grain $(0.26 \%)$ and straw $(0.19 \%)$ was recorded by the application of $6 \mathrm{~L} \mathrm{ha}^{-1}$ humic acid and the lowest $(0.23 \%$ and $0.12 \%$, respectively) was found in $\mathrm{HA}_{0}$ (Table 1). At optimum level of $\mathrm{HA}$, the roots were highly branched and this might have resulted an increase in surface area, which would have facilitated more efficient nutrient absorption (Mallikarjunarao et al., 1987). The highest $P$ content $(0.25 \%)$ in grain was observed by the application of 6 $\mathrm{t}$ ha ${ }^{-1}$ poultry manure which was similar to $3 \mathrm{t} \mathrm{ha}^{-1}$ and the lowest content $(0.23 \%)$ was recorded in $\mathrm{PM}_{0}$ (Table 2). The highest $P$ content $(0.18 \%)$ in straw was obtained by the application of $6 \mathrm{t}^{-1}$ poultry manure and the lowest $(0.15 \%)$ was found in $\mathrm{PM}_{0}$. This might be due to the application of poultry manure, which decreased the adsorption capacity and increased soluble $\mathrm{P}$ and phosphorus desorption (Amanullah et al., 2007). The $P$ content in grain and straw was significantly influenced by the interaction effect of humic acid and poultry manure (Table 3 ). The highest $P$ content $(0.27 \%)$ was obtained in grain at $T_{7}$ treatment by the combined application of $6 \mathrm{~L} \mathrm{ha}^{-1}$ humic acid and $3 \mathrm{tha}^{-1}$ poultry manure followed by $\mathrm{T}_{5}$, $T_{6}$ and $T_{8}$ treatments. The lowest content $(0.21 \%)$ was found in $T_{0}$. The highest $P$ content $(0.21 \%)$ was obtained in straw at $T_{7}$ treatment by the combined application of $6 \mathrm{~L} \mathrm{ha}^{-1}$ humic acid and $3 \mathrm{tha}{ }^{-1}$ poultry manure and the lowest content $(0.09 \%)$ was found in $\mathrm{T}_{0}$ (control) treatment. 
Table 1. Effect of humic acid on nutrient contents of $\mathrm{T}$. aman rice

\begin{tabular}{|c|c|c|c|c|c|c|c|c|c|c|c|c|}
\hline \multirow{2}{*}{ Treatments } & \multicolumn{2}{|c|}{ N (\%) } & \multicolumn{2}{|c|}{ P (\%) } & \multicolumn{2}{|c|}{ K (\%) } & \multicolumn{2}{|c|}{ S (\%) } & \multicolumn{2}{|c|}{$\mathrm{Ca}(\%)$} & \multicolumn{2}{|c|}{ Mg (\%) } \\
\hline & Grain & Straw & Grain & Straw & Grain & Straw & Grain & Straw & Grain & Straw & Grain & Straw \\
\hline${\text { Humic } \text { Acid }_{0}}$ & $1.29 c$ & $0.44 c$ & $0.23 c$ & $0.12 c$ & $0.63 c$ & $1.00 \mathrm{c}$ & $0.146 c$ & $0.047 c$ & $0.15 b$ & $0.43 b$ & $0.16 \mathrm{~b}$ & $0.59 c$ \\
\hline Humic Acid $_{3}$ & $1.34 b$ & $0.65 \mathrm{~b}$ & $0.24 b$ & $0.18 b$ & $0.76 \mathrm{~b}$ & $1.30 \mathrm{~b}$ & $0.156 b$ & $0.081 b$ & $0.27 a$ & $0.64 a b$ & $0.23 a$ & $0.72 b$ \\
\hline Humic Acid $_{6}$ & $1.38 a$ & $0.89 a$ & $0.26 a$ & $0.19 a$ & $0.81 a$ & $1.37 a$ & $0.162 a$ & $0.091 a$ & $0.26 a$ & $0.69 a$ & $0.22 a$ & $0.82 a$ \\
\hline CV (\%) & 1.50 & 3.76 & 7.77 & 8.77 & 2.54 & 11.76 & 6.46 & 18.42 & 7.00 & 6.76 & 13.28 & 5.60 \\
\hline
\end{tabular}

Table 2. Effect of poultry manure nutrient contents of $\mathrm{T}$. aman rice

\begin{tabular}{|c|c|c|c|c|c|c|c|c|c|c|c|c|}
\hline \multirow{2}{*}{ Treatments } & \multicolumn{2}{|c|}{ N (\%) } & \multicolumn{2}{|c|}{$\mathbf{P}(\%)$} & \multicolumn{2}{|c|}{ K (\%) } & \multicolumn{2}{|c|}{ S (\%) } & \multicolumn{2}{|c|}{$\mathrm{Ca}(\%)$} & \multicolumn{2}{|c|}{ Mg (\%) } \\
\hline & Grain & Straw & Grain & Straw & Grain & Straw & Grain & Straw & Grain & Straw & Grain & Straw \\
\hline Poultry manure $_{0}$ & $1.28 \mathrm{~b}$ & $0.59 c$ & $0.23 b$ & $0.15 b$ & $0.54 b$ & $1.11 \mathrm{~b}$ & $0.15 b$ & $0.064 c$ & $0.18 c$ & $0.50 \mathrm{~b}$ & $0.19 \mathrm{~b}$ & $0.67 c$ \\
\hline Poultry manure $_{3}$ & $1.37 a$ & $0.66 \mathrm{~b}$ & $0.25 a$ & $0.17 a b$ & $0.85 a$ & $1.28 \mathrm{a}$ & $0.16 a$ & $0.074 b$ & $0.24 b$ & $0.61 \mathrm{ab}$ & $0.23 a$ & $0.70 \mathrm{~b}$ \\
\hline Poultry manure $_{6}$ & $1.37 a$ & $0.74 a$ & $0.25 a$ & $0.18 a$ & $0.82 a b$ & $1.27 a$ & $0.16 a$ & $0.080 a$ & $0.27 a$ & $0.65 a$ & $0.20 \mathrm{~b}$ & $0.77 a$ \\
\hline CV (\%) & 0.81 & 1.99 & 4.32 & 6.41 & 2.95 & 23.36 & 3.61 & 12.31 & 16.61 & 5.00 & 13.75 & 6.20 \\
\hline
\end{tabular}

Table 3. Interaction effects of humic acid and poultry manure on nutrient contents of $\mathrm{T}$. aman rice

\begin{tabular}{|c|c|c|c|c|c|c|c|c|c|c|c|c|}
\hline \multirow{2}{*}{ Treatments } & \multicolumn{2}{|c|}{ N (\%) } & \multicolumn{2}{|c|}{$\mathbf{P}(\%)$} & \multicolumn{2}{|c|}{ K (\%) } & \multicolumn{2}{|c|}{ S (\%) } & \multicolumn{2}{|c|}{$\mathrm{Ca}(\%)$} & \multicolumn{2}{|c|}{$\mathrm{Mg}(\%)$} \\
\hline & Grain & Straw & Grain & Straw & Grain & Straw & Grain & Straw & Grain & Straw & Grain & Straw \\
\hline $\mathrm{HA}_{0} \mathrm{PM}_{0}$ & $1.21 \mathrm{f}$ & 0.36 & $0.21 c$ & $0.09 \mathrm{~d}$ & $0.06 f$ & 0.86 & $0.13 c$ & 0.030 & $0.02 \mathrm{e}$ & 0.34 & $0.13 d$ & $0.53 \mathrm{~g}$ \\
\hline $\mathrm{HA}_{0} \mathrm{PM}_{3}$ & $1.39 \mathrm{bc}$ & 0.45 & $0.24 b$ & $0.14 \mathrm{c}$ & $0.80 \mathrm{~cd}$ & 1.06 & $0.15 b$ & 0.050 & $0.17 d$ & 0.46 & $0.14 d$ & $0.59 f$ \\
\hline $\mathrm{HA}_{0} \mathrm{PM}_{6}$ & $1.26 \mathrm{f}$ & 0.51 & $0.22 \mathrm{bc}$ & $0.14 \mathrm{c}$ & $0.87 b$ & 1.07 & $0.18 a b$ & 0.060 & $0.26 \mathrm{bc}$ & 0.48 & $0.22 \mathrm{c}$ & $0.66 \mathrm{e}$ \\
\hline $\mathrm{HA}_{3} \mathrm{PM}_{0}$ & $1.29 \mathrm{e}$ & 0.58 & $0.23 b$ & $0.18 a b$ & 0.76de & 1.16 & $0.15 b$ & 0.070 & $0.27 a b$ & 0.57 & $0.22 \mathrm{c}$ & $0.68 d$ \\
\hline $\mathrm{HA}_{3} \mathrm{PM}_{3}$ & $1.32 \mathrm{~d}$ & 0.63 & $0.23 b$ & $0.17 \mathrm{~b}$ & $0.75 \mathrm{e}$ & 1.41 & $0.16 \mathrm{~b}$ & 0.083 & $0.27 a b$ & 0.65 & $0.22 \mathrm{~b}$ & $0.68 d$ \\
\hline $\mathrm{HA}_{3} \mathrm{PM}_{6}$ & $1.36 c$ & 0.75 & $0.26 a$ & $0.18 a b$ & $0.78 \mathrm{cde}$ & 1.31 & $0.16 b$ & 0.089 & $0.26 \mathrm{bc}$ & 0.70 & $0.23 b$ & $0.81 \mathrm{c}$ \\
\hline $\mathrm{HA}_{6} \mathrm{PM}_{0}$ & $1.40 \mathrm{~b}$ & 0.90 & $0.26 a$ & $0.19 a b$ & $0.82 \mathrm{c}$ & 1.36 & $0.13 c$ & 0.089 & $0.27 a b$ & 0.73 & $0.23 \mathrm{~b}$ & $0.82 b$ \\
\hline $\mathrm{HA}_{6} \mathrm{PM}_{3}$ & $1.43 a$ & 0.95 & $0.27 a$ & $0.21 a$ & $0.97 a$ & 1.41 & $0.19 a$ & 0.092 & $0.29 a$ & 0.77 & $0.22 \mathrm{c}$ & $0.81 \mathrm{c}$ \\
\hline $\mathrm{HA}_{6} \mathrm{PM}_{6}$ & $1.38 \mathrm{bc}$ & 0.83 & $0.26 a$ & $0.18 a b$ & $0.81 \mathrm{c}$ & 1.32 & $0.15 b$ & 0.092 & $0.24 c$ & 0.59 & $0.24 a$ & $0.84 a$ \\
\hline $\mathrm{CV}$ & 0.81 & 1.99 & 4.32 & 6.41 & 2.95 & 23.36 & 3.61 & 12.31 & 16.61 & 5.00 & 13.75 & 6.20 \\
\hline
\end{tabular}

Legend: $\mathrm{HA}=$ Humic acid, $\mathrm{PM}=$ Poultry manure

Potassium: The content of $\mathrm{K}$ in grain and straw was significantly influenced by the application of humic acid and poultry manure. The highest $\mathrm{K}$ content in grain $(0.81 \%)$ and straw $(1.37 \%)$ was obtained by the application of $6 \mathrm{~L} \mathrm{ha}^{-1}$ humic acid and the lowest content $(0.63$ and $1.00 \%$, respectively) was obtained in $\mathrm{HA}_{0}$ (Table 1). The highest $\mathrm{K}$ content in grain $(0.85 \%)$ and straw $(1.28 \%)$ was obtained by the application of $3 \mathrm{t} \mathrm{ha}^{-1}$ poultry manure and the lowest content $\left(0.54 \%\right.$ and $1.11 \%$, respectively) was found in $\mathrm{PM}_{0}$ (Table 2). The interaction effects of humic acid and poultry manure on $\mathrm{K}$ content in grain was significant though it was not significant in straw (Table 3$)$. The highest $\mathrm{K}$ content $(0.97 \%)$ in grain was observed by the combined application of $6 \mathrm{~L} \mathrm{ha}^{-1}$ humic acid and $3 \mathrm{tha}^{-1}$ poultry manure and the lowest content $(0.06 \%)$ was found in $T_{0}$ (control) treatment.

Sulphur: The content of $S$ in grain and straw was significantly influenced by the incorporation of humic acid and poultry manure. The highest $S$ content in grain $(0.162 \%)$ and straw $(0.091 \%)$ was obtained by the application of $6 \mathrm{~L} \mathrm{ha}^{-1}$ humic acid and the lowest content $(0.146$ and $0.047 \%$, respectively) was obtained in $\mathrm{HA}_{0}$ (Table 1 ). The highest $\mathrm{S}$ content in grain $(0.16 \%)$ and straw $(0.080 \%)$ was recorded by the application of $6 \mathrm{t} \mathrm{ha}^{-1}$ poultry manure and the lowest $(0.15 \%$ and $0.064 \%$, respectively) was obtained in $\mathrm{PM}_{0}$ (Table 2). The interaction effects of humic acid and poultry manure increased $\mathrm{S}$ content significantly in grain (Table 3$)$. The highest $S$ content $(0.19 \%)$ in grain was observed by the combined application of $6 \mathrm{~L} \mathrm{ha}^{-1}$ humic acid and $3 \mathrm{t} \mathrm{ha}^{-1}$ poultry manure and the lowest $(0.13 \%)$ was found in $\mathrm{T}_{0}$ (control) treatment. There was no significant interaction effect of humic acid and poultry manure on $\mathrm{S}$ content in straw.

Calcium: Calciam content in grain and straw was significantly influenced by the application of humic acid and poultry manure. The highest Ca content $(0.27 \%)$ in grain was obtained by the application of $3 \mathrm{~L} \mathrm{ha}^{-1}$ humic acid followed by $6 \mathrm{~L} \mathrm{ha}{ }^{-1}$ and the lowest concentration $(0.15 \%)$ was in control. In straw, the highest Ca content $(0.69 \%)$ was recorded by the application of $6 \mathrm{~L} \mathrm{ha}^{-1}$ humic acid and the lowest $(0.43 \%)$ was in $\mathrm{HA}_{0}$ (Table 1). The highest Ca content was obtained in grain $(0.27 \%)$ and straw $(0.65 \%)$ by the application of $6 \mathrm{t} \mathrm{ha}^{-1}$ poultry manure and the lowest content $\left(0.18 \%\right.$ and $0.50 \%$, respectively) was found in $\mathrm{PM}_{0}$ (Table 2). The interaction effect of humic acid and poultry manure significantly increased the $\mathrm{Ca}$ content 
in grain (Table 3 ). The highest Ca content $(0.29 \%)$ was obtained in grain by the combined application of 6 $\mathrm{L} \mathrm{ha}^{-1}$ humic acid and $3 \mathrm{t} \mathrm{ha}^{-1}$ poultry manure and the lowest value $(0.02 \%)$ was found in control $\left(\mathrm{T}_{0}\right)$ treatment. There was no significant interaction effect of humic acid and poultry manure on Ca content in straw.

Magnesium: The content of $\mathrm{Mg}$ in grain and straw was significantly influenced by the application of humic acid and poultry manure. The highest Mg content $(0.23 \%)$ in grain was obtained by the application of $3 \mathrm{~L} \mathrm{ha}{ }^{-1}$ humic acid and the lowest value $(0.16 \%)$ was obtained in $\mathrm{HA}_{0}$ (Table 1$)$. The highest $\mathrm{Mg}$ content $(0.82 \%)$ in straw was found by the application of $6 \mathrm{~L} \mathrm{ha}^{-1}$ humic acid and the lowest $(0.59 \%)$ was recorded in $\mathrm{HA}_{0}$. The highest $\mathrm{Mg}$ content $(0.23 \%)$ was recorded in grain by the application of $3 \mathrm{tha}^{-1}$ poultry manure and the lowest value $(0.19 \%)$ was observed in $\mathrm{PM}_{0}$ (Table 2$)$. The highest $\mathrm{Mg}$ content $(0.77 \%)$ was obtained in straw by the application of $6 \mathrm{t} \mathrm{ha}^{-1}$ poultry manure and the lowest value $(0.67 \%)$ was found in $\mathrm{PM}_{0}$. Magnesium content was significantly influenced due to the combined application of humic acid and poultry manure in the grain and straw of rice (Table 3). The highest Mg content in grain $(0.24 \%)$ and straw $(0.84 \%)$ was obtained by the combined application of $6 \mathrm{~L} \mathrm{ha}^{-1}$ humic acid and $6 \mathrm{t} \mathrm{ha}^{-1}$ poultry manure and the lowest content $\left(0.13\right.$ and $0.53 \%$, respectively) was found in control $\left(T_{0}\right)$ treatment.

\section{Nutrient uptake by rice grain and straw}

Nitrogen: Nitrogen uptake by grain and straw of BRRI dhan39 was significantly influenced by the application of humic acid and poultry manure. The highest $\mathrm{N}$ uptake in grain $\left(44.16 \mathrm{~kg} \mathrm{ha}^{-1}\right)$ and straw ( $75.21 \mathrm{~kg} \mathrm{ha}^{-1}$ ) was obtained by the application of $6 \mathrm{~L} \mathrm{ha}^{-1}$ humic acid and the lowest uptake (39.86 and $36.17 \mathrm{~kg} \mathrm{ha}^{-1}$, respectively) was found in $\mathrm{HA}_{0}$ (Table 4). Saalbach (1956) stated that humic acid enhanced the uptake and content of nitrogen in rye. The highest $\mathrm{N}$ uptake was obtained in grain $\left(46.88 \mathrm{~kg} \mathrm{ha}^{-1}\right)$ and straw $\left(69.09 \mathrm{~kg} \mathrm{ha}^{-1}\right)$ by the use of $6 \mathrm{t} \mathrm{ha}^{-1}$ poultry manure and the lowest uptake $\left(37.26\right.$ and $50.19 \mathrm{~kg} \mathrm{ha}^{-1}$, respectively) was recorded in $\mathrm{PM}_{0}$ (Table 5). The uptake of $\mathrm{N}$ by grain and straw of BRRI dhan39 was significantly increased due to the interaction effects of humic acid and poultry manure (Table 6). The highest $\mathrm{N}$ uptake in grain $\left(58.20 \mathrm{~kg} \mathrm{ha}^{-1}\right)$ and straw $\left(97.66 \mathrm{~kg} \mathrm{ha}^{-1}\right)$ was obtained by the combined application of $6 \mathrm{~L} \mathrm{ha}^{-1}$ humic acid and $3 \mathrm{tha}^{-1}$ poultry manure and the lowest uptake (28.68 and $28.73 \mathrm{~kg}$ $\mathrm{ha}^{-1}$, respectively) was found in control $\left(\mathrm{T}_{0}\right)$ treatment.

Table 4. Effect of humic acid on the $\mathrm{N}, \mathrm{P}, \mathrm{K}, \mathrm{S}, \mathrm{Ca}$ and $\mathrm{Mg}$ uptake by $\mathrm{T}$. aman rice

\begin{tabular}{|c|c|c|c|c|c|c|c|c|c|c|c|c|}
\hline \multirow{2}{*}{ Treatments } & \multicolumn{2}{|c|}{$N\left(\mathrm{~kg} \mathrm{ha}^{-1}\right)$} & \multicolumn{2}{|c|}{$P\left(\mathrm{~kg} \mathrm{ha}^{-1}\right)$} & \multicolumn{2}{|c|}{$\mathrm{K}\left(\mathrm{kg} \mathrm{ha}^{-1}\right)$} & \multicolumn{2}{|c|}{$S\left(\mathrm{~kg} \mathrm{ha}^{-1}\right)$} & \multicolumn{2}{|c|}{$\mathrm{Ca}\left(\mathrm{kg} \mathrm{ha}^{-1}\right)$} & \multicolumn{2}{|c|}{$\mathrm{Mg}\left(\mathrm{kg} \mathrm{ha}^{-1}\right)$} \\
\hline & Grain & Straw & Grain & Straw & Grain & Straw & Grain & Straw & Grain & Straw & Grain & Straw \\
\hline Humic acid & $39.86 c$ & $36.17 \mathrm{c}$ & $7.11 \mathrm{c}$ & $9.86 \mathrm{c}$ & $19.47 c$ & $82.20 \mathrm{c}$ & $4.51 \mathrm{~b}$ & $3.86 c$ & $4.64 b$ & $35.35 c$ & $4.94 b$ & $48.50 \mathrm{c}$ \\
\hline Humic acid 3 & $41.54 \mathrm{~b}$ & $54.15 b$ & $7.44 \mathrm{~b}$ & $14.99 \mathrm{~b}$ & $23.56 b$ & $108.29 b$ & $4.84 a$ & $6.75 b$ & $8.37 a$ & $53.31 b$ & $7.13 a$ & $59.98 \mathrm{~b}$ \\
\hline Humic acid $_{6}$ & $44.16 a$ & $75.21 a$ & $8.32 a$ & $16.06 a$ & $25.92 a$ & $115.77 \mathrm{a}$ & $5.18 a$ & $7.69 a$ & $8.32 a$ & $58.31 a$ & $7.04 a$ & $69.29 a$ \\
\hline CV (\%) & 7.21 & 4.34 & 10.78 & 9.14 & 8.86 & 11.81 & 9.35 & 18.07 & 10.61 & 6.97 & 14.87 & 6.69 \\
\hline
\end{tabular}

Table 5. Effect of poultry manure on the N, P, K, S, Ca and Mg uptake by T. aman rice

\begin{tabular}{|c|c|c|c|c|c|c|c|c|c|c|c|c|}
\hline \multirow{2}{*}{ Treatments } & \multicolumn{2}{|c|}{$N\left(\mathrm{~kg} \mathrm{ha}^{-1}\right)$} & \multicolumn{2}{|c|}{$P\left(\mathrm{~kg} \mathrm{ha}^{-1}\right)$} & \multicolumn{2}{|c|}{$K\left(\mathrm{~kg} \mathrm{ha}^{-1}\right)$} & \multicolumn{2}{|c|}{$S\left(k h^{-1}\right)$} & \multicolumn{2}{|c|}{$\mathrm{Ca}\left(\mathrm{kg} \mathrm{ha}^{-1}\right)$} & \multicolumn{2}{|c|}{$M g\left(k g ~ h a^{-1}\right)$} \\
\hline & Grain & Straw & Grain & Straw & Grain & Straw & Grain & Straw & Grain & Straw & Grain & Straw \\
\hline Poultry manure $_{0}$ & $37.26 \mathrm{c}$ & $50.19 c$ & $6.84 c$ & $12.59 \mathrm{~b}$ & $17.04 \mathrm{c}$ & $93.10 \mathrm{~b}$ & $4.40 \mathrm{~b}$ & $5.48 c$ & $5.54 c$ & $42.09 c$ & $5.69 \mathrm{~b}$ & $56.29 c$ \\
\hline Poultry manure $_{3}$ & $41.87 \mathrm{~b}$ & $61.33 b$ & $7.50 \mathrm{~b}$ & 15.29ab & $25.98 b$ & $116.47 a$ & $4.82 a b$ & $6.81 \mathrm{~b}$ & 7. & $5 b$ & $9 a$ & $79 b$ \\
\hline Poultry manure $_{6}$ & $46.88 \mathrm{a}$ & $69.09 a$ & $8.48 a$ & $16.35 a$ & $28.12 a$ & $117.55 a$ & $5.38 a$ & $7.46 a$ & $9.07 a$ & $60.32 a$ & $6.57 \mathrm{ab}$ & $71.44 a$ \\
\hline CV (\%) & 3.78 & 5.38 & 0.76 & 2.78 & 0.66 & 0.41 & 3.41 & 6.28 & 4.43 & 1.17 & 4.44 & 3.15 \\
\hline
\end{tabular}

Phosphorus: The uptake of $\mathrm{P}$ by both grain and straw of BRRI dhan39 was significantly influenced by the application of humic acid and poultry manure. The highest $P$ uptake in grain $\left(8.32 \mathrm{~kg} \mathrm{ha}^{-1}\right)$ and straw $\left(16.06 \mathrm{~kg} \mathrm{ha}^{-1}\right)$ was recorded at $\mathrm{HA}_{3}$. The lowest uptake (7.11 and $9.86 \mathrm{~kg} \mathrm{ha}^{-1}$, respectively) was found at $\mathrm{HA}_{0}$ (Table 4). Different levels of humic acid had significant effect on nitrogen and phosphorus uptake by oats. The efficiency indices of various humic acids ranged between 25 and 65 per cent (Mishra and Srivastava, 1988). The highest $P$ uptake in grain $\left(8.48 \mathrm{~kg} \mathrm{ha}^{-1}\right)$ and straw $\left(16.35 \mathrm{~kg} \mathrm{ha}^{-1}\right)$ was obtained in $\mathrm{PM}_{6}$ i.e. the application of $6 \mathrm{t} \mathrm{ha}^{-1}$ poultry manure and the lowest uptake $\left(6.84\right.$ and $12.59 \mathrm{~kg} \mathrm{ha}^{-1}$, respectively) was found in $\mathrm{PM}_{0}$ (Table 5). Anion exchange phenomenon could be another reason for increasing $P$ availability and higher $P$ uptake by rice (Deb and Datta, 1967). The difference in $P$ uptake by grain and straw due to interaction effects of humic acid and poultry manure was also significant (Table 6). The highest $P$ uptake in grain $\left(10.99 \mathrm{~kg} \mathrm{ha}^{-1}\right)$ and straw $\left(21.29 \mathrm{~kg} \mathrm{ha}^{-1}\right)$ was obtained by the combined application of $6 \mathrm{~L} \mathrm{ha}^{-1}$ humic acid and $3 \mathrm{tha}^{-1}$ poultry manure and the lowest uptake $(4.98$ and $7.18 \mathrm{~kg}$ ha, respectively) was found in control ( $\left.T_{0}\right)$ treatment. Jelanic et al. (1966) reported that HA from lignite increased $\mathrm{P}$ content and uptake in maize plants. 
Potassium: Potassium uptake by both grain and straw of BRRI dhan39 was significantly influenced by the application of humic acid and poultry manure. The highest $\mathrm{K}$ uptake in grain $\left(25.92 \mathrm{~kg} \mathrm{ha}^{-1}\right)$ and straw $\left(115.77 \mathrm{~kg} \mathrm{ha}^{-1}\right)$ was obtained by the application of $6 \mathrm{~L} \mathrm{ha}^{-1}$ humic acid and the lowest uptake (19.47 and $82.20 \mathrm{~kg} \mathrm{ha}^{-1}$, respectively) was found in $\mathrm{HA}_{0}$ (Table 4). The highest $\mathrm{K}$ uptake in grain $\left(28.12 \mathrm{~kg} \mathrm{ha}^{-1}\right)$ and straw $\left(117.55 \mathrm{~kg} \mathrm{ha}^{-1}\right)$ was obtained by the application of $6 \mathrm{t} \mathrm{ha}^{-1}$ poultry manure and the lowest value (17.04 and $93.10 \mathrm{~kg} \mathrm{ha}^{-1}$, respectively) was found in $\mathrm{PM}_{0}$ (Table 5). The uptake of $\mathrm{K}$ was significantly influenced in grain due to the interaction effect of humic acid and poultry manure (Table 6). The highest $\mathrm{K}$ uptake in grain $\left(39.48 \mathrm{~kg} \mathrm{ha}^{-1}\right.$ ) was obtained by the combined use of $6 \mathrm{~L} \mathrm{ha}^{-1}$ humic acid and $3 \mathrm{t} \mathrm{ha}^{-1}$ poultry manure and the lowest uptake $\left(1.42 \mathrm{~kg} \mathrm{ha}^{-1}\right)$ was found in $\mathrm{T}_{0}$. The uptake of $\mathrm{K}$ was not significantly influenced in straw due to the interaction effect of humic acid and poultry manure.

Table 6. Interaction effect of different doses of humic acid and poultry manure on $\mathrm{N}, \mathrm{P}, \mathrm{K}, \mathrm{S}, \mathrm{Ca}$ and $\mathrm{Mg}$ uptake by $\mathrm{T}$. aman rice

\begin{tabular}{|c|c|c|c|c|c|c|c|c|c|c|c|c|}
\hline \multirow{2}{*}{ Treatments } & \multicolumn{2}{|c|}{$N\left(k g ~ h a^{-1}\right)$} & \multicolumn{2}{|c|}{$P\left(\mathrm{~kg} \mathrm{ha}^{-1}\right)$} & \multicolumn{2}{|c|}{$K\left(\mathrm{~kg} \mathrm{ha}^{-1}\right)$} & \multicolumn{2}{|c|}{$S\left(\mathrm{~kg} \mathrm{ha}^{-1}\right)$} & \multicolumn{2}{|c|}{$\mathrm{Ca}\left(\mathrm{kg} \mathrm{ha}^{-1}\right)$} & \multicolumn{2}{|c|}{$M g\left(k a^{-1}\right)$} \\
\hline & Grain & Straw & Grain & Straw & Grain & Straw & Grain & Straw & Grain & Straw & Grain & Straw \\
\hline $\mathrm{HA}_{0} \mathrm{PM}_{0}$ & $28.68 d$ & $28.73 f$ & $4.98 \mathrm{e}$ & $7.18 d$ & $1.42 d$ & 68.63 & $3.08 d$ & 2.39 & $0.47 f$ & 27.13 & $3.08 \mathrm{e}$ & $42.29 \mathrm{e}$ \\
\hline $\mathrm{HA}_{0} \mathrm{PM}_{3}$ & $41.28 a$ & $45.00 \mathrm{e}$ & $7.13 c$ & $14.00 \mathrm{c}$ & $23.76 c$ & 106.00 & $4.46 \mathrm{bc}$ & 5.00 & $5.05 \mathrm{e}$ & 46.00 & $4.16 d$ & $59.00 d$ \\
\hline $\mathrm{HA}_{0} \mathrm{PM}_{6}$ & $37.55 \mathrm{c}$ & 51.05de & $6.56 \mathrm{~d}$ & $14.01 \mathrm{c}$ & $25.93 b$ & 107.11 & $5.36 \mathrm{~b}$ & 6.01 & $7.75 d$ & 48.05 & $6.56 \mathrm{c}$ & $66.07 \mathrm{c}$ \\
\hline $\mathrm{HA}_{3} \mathrm{PM}_{0}$ & 38.70 & $46.98 \mathrm{e}$ & $6.90 \mathrm{~d}$ & $14.58 \mathrm{c}$ & $22.80 \mathrm{c}$ & 93.96 & $4.50 \mathrm{~b}$ & 5.67 & $8.10 c$ & 46.17 & $6.60 c$ & 55.08de \\
\hline $\mathrm{HA}_{3} \mathrm{PM}_{3}$ & $40.26 c$ & $55.25 d$ & $7.02 \mathrm{c}$ & $14.91 \mathrm{~b}$ & $22.88 c$ & 123.66 & $4.88 \mathrm{~b}$ & 7.28 & $8.24 \mathrm{bc}$ & 57.01 & $6.71 \mathrm{c}$ & $59.64 d$ \\
\hline $\mathrm{HA}_{3} \mathrm{PM}_{6}$ & $43.93 b$ & $61.73 c$ & $8.40 \mathrm{~b}$ & $14.81 \mathrm{~b}$ & $25.19 \mathrm{~b}$ & 107.81 & $5.17 \mathrm{~b}$ & 7.32 & $8.40 \mathrm{~b}$ & 57.61 & $7.43 b$ & $66.66 \mathrm{c}$ \\
\hline $\mathrm{HA}_{6} \mathrm{PM}_{0}$ & $44.38 \mathrm{~b}$ & $74.61 \mathrm{~b}$ & $8.24 b$ & $15.75 b$ & $25.99 b$ & 112.74 & $4.12 c$ & 7.38 & $8.56 \mathrm{~b}$ & 60.52 & $7.29 b$ & $67.98 \mathrm{c}$ \\
\hline $\mathrm{HA}_{6} \mathrm{PM}_{3}$ & $58.20 a$ & $97.66 \mathrm{a}$ & $10.99 a$ & $21.59 a$ & $39.48 a$ & 144.95 & $7.73 a$ & 9.46 & $11.80 \mathrm{a}$ & 79.16 & $7.35 b$ & $76.63 b$ \\
\hline $\mathrm{HA}_{6} \mathrm{PM}_{6}$ & $46.09 \mathrm{~b}$ & $78.52 \mathrm{~b}$ & $8.68 b$ & $17.03 \mathrm{~b}$ & $27.05 b$ & 124.87 & $5.01 b$ & 8.70 & $8.02 b c$ & 55.81 & $9.77 a$ & $86.35 a$ \\
\hline CV (\%) & 3.78 & 5.38 & 0.76 & 2.78 & 0.66 & 0.41 & 3.41 & 6.28 & 4.43 & 1.17 & 4.44 & 3.15 \\
\hline
\end{tabular}

Legend: $\mathrm{HA}=$ Humic acid, $\mathrm{PM}=$ Poultry manure

Sulphur: The uptake of $S$ by both grain and straw was significantly influenced due to the application of humic acid and poultry manure. The highest $S$ uptake in grain $\left(5.18 \mathrm{~kg} \mathrm{ha}^{-1}\right)$ and straw $\left(7.69 \mathrm{~kg} \mathrm{ha}{ }^{-1}\right)$ was obtained by the application of $6 \mathrm{~L} \mathrm{ha}^{-1}$ humic acid and the lowest uptake $\left(4.51\right.$ and $3.86 \mathrm{~kg} \mathrm{ha}^{-1}$, respectively) was found in $\mathrm{HA}_{0}$ (Table 4). Raina and Goswami (1988) reported a significant increase in the uptake of $\mathrm{N}, \mathrm{P}, \mathrm{Cu}, \mathrm{S}$ and $\mathrm{Fe}$ upto $20 \mathrm{ppm}$ carbon as humic acid over control. The highest $\mathrm{S}$ uptake in grain $\left(5.38 \mathrm{~kg} \mathrm{ha}^{-1}\right)$ and straw $\left(7.46 \mathrm{~kg} \mathrm{ha}^{-1}\right)$ was obtained by the use of $6 \mathrm{t} \mathrm{ha}^{-1}$ poultry manure and the lowest value (4.40 and $5.48 \mathrm{~kg} \mathrm{ha}^{-1}$, respectively) was found in $\mathrm{PM}_{0}$ (Table 5). Sulphur uptake was significantly influenced in grain due to the interaction effects of humic acid and poultry manure (Table 6). The highest $S$ uptake in grain $\left(7.73 \mathrm{~kg} \mathrm{ha}^{-1}\right)$ was obtained by the combined use of $6 \mathrm{~L} \mathrm{ha}^{-1}$ humic acid and $3 \mathrm{t} \mathrm{ha} \mathrm{T}^{-1}$ poultry manure and the lowest uptake $\left(3.08 \mathrm{~kg} \mathrm{ha}^{-1}\right)$ was found in $T_{0}$ treatment. The uptake of $S$ was not significantly influenced in straw due to the interaction effects of humic acid and poultry manure.

Calcium: Calcium uptake by both grain and straw of BRRI dhan39 was significantly influenced by the application of humic acid and poultry manure The highest Ca uptake in grain $\left(8.37 \mathrm{~kg} \mathrm{ha}^{-1}\right)$ and straw $\left(58.31 \mathrm{~kg} \mathrm{ha}^{-1}\right)$ was obtained by the application of 3 and @ $6 \mathrm{~L} \mathrm{ha}^{-1}$ humic acid, respectively and the lowest uptake (4.64 and $35.35 \mathrm{~kg} \mathrm{ha}^{-1}$, respectively) was found in $\mathrm{HA}_{0}$ (Table 4). The highest Ca uptake in grain $\left(9.07 \mathrm{~kg} \mathrm{ha}^{-1}\right)$ and straw $\left(60.32 \mathrm{~kg} \mathrm{ha}^{-1}\right)$ was obtained by the application of $6 \mathrm{t} \mathrm{ha}^{-1}$ poultry manure and the lowest value in grain (5.54 and $42.09 \mathrm{~kg} \mathrm{ha}^{-1}$, respectively) was found in $\mathrm{PM}_{0}$ (Table 5). The uptake of $\mathrm{Ca}$ was significantly influenced in grain due to the interaction effect of humic acid and poultry manure (Table 6). The highest $\mathrm{Ca}$ uptake in grain $\left(11.80 \mathrm{~kg} \mathrm{ha}^{-1}\right)$ was obtained by the combined use of 6 $\mathrm{L} \mathrm{ha} \mathrm{h}^{-1}$ humic acid and $3 \mathrm{t} \mathrm{ha}^{-1}$ poultry manure and the lowest uptake $\left(0.47 \mathrm{~kg} \mathrm{ha}^{-1}\right)$ was found in $\mathrm{T}_{0}$. The uptake of $\mathrm{Ca}$ was not significantly influenced in straw due to the interaction effect of humic acid and poultry manure.

Magnesium: Magnesium uptake by both grain and straw of BRRI dhan39 was significantly influenced due to the application of humic acid and poultry manure. The highest $\mathrm{Mg}$ uptake in grain $\left(7.13 \mathrm{~kg} \mathrm{ha}^{-1}\right)$ and straw (69.29 kg ha ${ }^{-1}$ ) was obtained by the application of 3 and @ $6 \mathrm{~L} \mathrm{ha}^{-1}$ humic acid, respectively and the lowest uptake (4.94 and $48.50 \mathrm{~kg} \mathrm{ha}^{-1}$, respectively) was found when $0 \mathrm{~L} \mathrm{ha}^{-1}$ humic acid was applied (Table 4). Application of $10 \mathrm{~kg} \mathrm{HA} \mathrm{ha}^{-1}$ as potassium humate along with $75 \%$ recommended doses of fertilizers found to increase the crude protein content and mineral nutrition $(\mathrm{P}, \mathrm{K}, \mathrm{Ca}, \mathrm{Mg}, \mathrm{Zn}$, $\mathrm{Cu}_{1} \mathrm{Fe}$ and $\mathrm{Mn}$ ) of Amaranthus (Bama and Selvakumari, 2001). The highest $\mathrm{Mg}$ uptake in grain $(6.99 \mathrm{~kg}$ $\left.\mathrm{ha}^{-1}\right)$ and straw (71.44 $\left.\mathrm{kg} \mathrm{ha}^{-1}\right)$ was obtained by the application of 3 and $6 \mathrm{t} \mathrm{ha}^{-1}$ poultry manure, respectively and the lowest uptake (5.69 and $56.29 \mathrm{~kg} \mathrm{ha}^{-1}$, respectively) was found in $\mathrm{PM}_{0}$ (Table 5). The 
uptake of $\mathrm{Mg}$ by both grain and straw was significantly influenced due to the interaction effects of humic acid and poultry manure (Table 6). The highest $\mathrm{Mg}$ uptake in grain $\left(9.77 \mathrm{~kg} \mathrm{ha}^{-1}\right)$ and straw $(86.35 \mathrm{~kg} \mathrm{ha}$ ${ }^{1}$ ) was recorded at $\mathrm{T}_{8}$ treatment by the combined use of $6 \mathrm{~L} \mathrm{ha}^{-1}$ humic acid and $6 \mathrm{t} \mathrm{ha}^{-1}$ poultry manure. The lowest uptake in grain and straw (3.08 and $42.29 \mathrm{~kg} \mathrm{ha}^{-1}$, respectively) were found in treatment $\mathrm{T}_{0}$ (control) treatment.

\section{Conclusion}

Nutrient content in both grain and straw were significantly influenced by the application of HA and PM along with recommended doses of chemical fertilizers. The highest $\mathrm{N}, \mathrm{P}, \mathrm{K}, \mathrm{S}$, and Ca contents in grain and straw were obtained from $\mathrm{T}_{7}$ treatment. Only the highest content of $\mathrm{Mg}$ in grain and straw was found in $\mathrm{T}_{8}$ treatment. Control treatment gave the lowest content in all the parameters studied. However, the application of $3 \mathrm{t} \mathrm{ha}^{-1} \mathrm{PM}$ along with $6 \mathrm{~L} \mathrm{ha}^{-1} \mathrm{HA}$ showed the better performance than PM or HA alone. It is, therefore, concluded that the incorporation of $6 \mathrm{~L} \mathrm{ha}^{-1} \mathrm{HA}$ plus $3 \mathrm{tha}^{-1} \mathrm{PM}$ with recommended doses of $\mathrm{N}, \mathrm{P}, \mathrm{K}, \mathrm{S}, \mathrm{Ca}$ and $\mathrm{Mg}$ fertilizers should be used for $\mathrm{T}$. aman rice particularly BRRI dhan39.

\section{References}

Amanullah, M.M., Somasundaram, E., Vaiyapuri, K. and Sathyamoorthi, K. 2007. Poultry Manure to Crops-A review. Agric. Rev. 28(3): 216-222.

Anonymous. 2010. Humic and fulvic acids: The black gold of agriculture? [Available at http://www.humintech.com/ pdf/humicfulvicacids.pdf]

Bama, K. S. and Selvakumari, G. 2001. Effect of humic acid on growth, yield and nutrition of amaranthus. South Indian Hort. 49: 155156.

BRRI (Bangladesh Rice Research Institute). 2007. Bangladesh Rice Knowledge Bank. [Available at http://riceknowledgebank.brri.org.]

Cacco, G. and Dell'Agnolla, G. 1984. Plant growth regulator activity of soluble humic substances. Canadian J. Soil Sci. 64: $25-28$.

Chen, Y., Magen, H. and Clapp, C. E. 2001. Plant growth stimulation by humic substances and their complexes with iron. Proceedings of International Fertiliser Society, Israel. pp 14.

Deb, D.L. and Datta, N.P. 1967. Effect of association of ions on phosphorus retention in soils under variable anion concentrations. Adv. Plant Sci. 26 (1): 432-444

Gomez, K. A. and Gomez, A. A. 1984. Statistical Procedures for Agricultural Research. $2^{\text {nd }}$ edn., A Wiley-Interscience Publication, New York, USA.

Govindasamy, R. and Chandrasekaran, S. 2002. Effect of graded levels of humic acid with and without $\mathrm{N}$ on the performance of low land rice. p. 5. Inter. National seminar on recent trends on the use of humic substances for sustainable agriculture, Annamalai University, Tamil Nadu.

IRRI (International Rice Research Institute). 2006. World Rice Statistics. Intl. Rice Res. Inst. [Available at http://www.irri.org/science/wrs] Jackson, M.L. 1962. Soil Chemical Analysis. Prentic Hall of India Engle Wood Cliffs, N. J. USA. pp 55-56.

Jelanic, D.B., Hajdukovic, M. and Aleksic, Z. 1966. The influence of humic substances on phosphate utilization from labelled superphosphate. In: Report of FAO/IAEA proceedings. Pergamon Press, Oxford. pp 109-112.

Mallikarajunarao, M., Govindasamy, R. and Chandrasekaran, S. 1987. Effect of humic acid on sorghum vulgare var. CSH-9. Indian J. Agron. 25(3): 364-367.

Mishra, B. and Srivastava, L.L. 1988. Physiological properties of humic acids isolated from some major soil associations of Bihar. J. Indian Soc. Soil Sci. 36: 83-89.

Nardi, S., Tosoni, M., Pizzeghello, D., Provenzano, M.R., Cilenti, A., Sturaro, A., Rella, R. and Vianello, A. 2005. Chemical characteristics and biological activity of organic substances extracted from soils by root exudates. Soil Sci. Soc. Am. J. 69 : 2012-2019.

Page, A.L., Miller, R.H. and Keeney, D.R. (eds.) 1982. Methods of Soil Analysis. Part II, 2nd edn. Amer. Soc. Agron. Inc. Madison, Wisconsin, USA. pp 516-530.

Petronio, P., Vitorovic, D. and Jablanovic, M. 1982. Investigations of the biological effect of HA. Acta Biol. Med. Exp. 7 (1): $21-25$.

Pettit, R.E. 2004. Organic matter, humus, humate, humic acid, fulvic acid and humin: Their importance in soil fertility and plant health [Available at www.humate.info/mainpage.htm.]

Raina, J.N. and Goswami, K.P. 1988. Effect of fulvic acid and fulvates on the growth and nutrient uptake by maize plant. J. Indian Soc. Soil Sci. 36: 264-268.

Rengrudkij, P.H. and Partida, G.J. 2003. The effects of humic acid and phosphoric acid on grafted Hass avocado on Mexican seedling rootstocks. Actas V Congreso Mundial del Aguacate. pp 395-400.

Saalbach, E. 1956. The influence of humic substances on the metabolism of plants. Sixth Congress Int. Dela Sci. de Sol. Paris; pp 107111.

Tandon, H.L.S. (eds.) 1995. Methods of Analysis of Soils, Plants, Waters and Fertilizers. Fertilizer Development and Consulation Organization, New Delhi, India. pp 87-92.

Trevisan, S., Pizzeghello, D., Ruperti, B., Francioso, O., Sassi, A., Palme, K., Quaggiotti, S. and Nardi, S. 2009. Humic substances induce lateral root formation and expression of the early auxin-responsive IAA19 gene and DR5 synthetic element in Arabidopsis. Plant Biol. 12: 604-614.

Turkmen, O., Dursun, A., Turan, M. and Erdinc, C. 2004. Calcium and humic acid affect seed germination, growth and nutrient content of tomato (Lycopersicon esculentum L.) seedlings under saline soil conditions. Acta Agric. Scandinavica, Section B- Plant Soil Sci. 54(3): 168- 174. 